Original Article (short paper)

\title{
The educational purposes of Physical Education - curricular dialogues between Brazil and Portugal
}

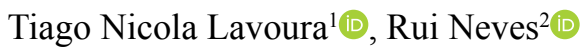 \\ ${ }^{1}$ Universidade Estadual de Santa Cruz, Department of Health Sciences, Ilhéus, BA, Brazil; \\ ${ }^{2}$ Universidade de Aveiro, Department of Education and Psychology, Aveiro, Portugal
}

\begin{abstract}
Aim: The paper aims to analyse the educational purposes of Physical Education (PE) present in the national documents and programmes created in Brazil and Portugal that are geared towards its teaching in elementary schools. Methods: Since the research is of a theoretical-conceptual, documentary type character, content analysis was used to identify the category matrices of the sources analysed. Results: The results suggest approaches and specific features in skills development which are analysed and discussed based on the scientific production of the area's academic-professional field. The predominance of operational competencies is limited towards practicing PE activities, which is consistent with the pedagogical theory of competency formation. Conclusion: This concept maintains that tacit knowledge and sensory experiences are essential for performance. However, the implementation of cognitive and affective competencies are important tools for performance, particularly with adolescent students.
\end{abstract}

Keywords: school physical education, educational purposes, skills, teaching, learning.

\section{Introduction}

The presence of Physical Education (PE) in the basic schooling curricula of different countries has generated regular discussions and debates both in the academic field and the political field regarding its educational purposes.

This is because in spite of it being a compulsory requirement, mostly in European and Latin American countries ${ }^{1,2}$, the historical linkage of PE to the curricular idea of practising physical exercises of a gymnastic and/or sporting nature, characterised as a mere physical experience whose purpose is associated with the morpho functional and recreational benefits, still needs to be overcome $\mathrm{e}^{3,4,5}$.

Faced with this question, some theoretical-methodological propositions have been announced and systematised in the academic-professional field, affirming new conceptions of teaching practices in the context of the concept and meaning of PE in school.

Such propositions are based on several epistemological matrices with different implications for the (re)definition of the teaching object, contents and educational purposes, seeking to be presented as an alternative to the biological oriented conception of PE based on the medical-hygienic sciences and behavioural psychology.

As evidenced by Devís ${ }^{6}$, in the late 1990 s and early 2000 s there was a marked development and expansion of international scientific literature regarding studies and research based on the what is known as the socio-critical perspective of PE. Such studies were and continue to be disseminated by different researchers, with emphasis in the United Kingdom ${ }^{7,8}$, Sweden ${ }^{9}$, France $^{10,11}$, Spain $^{12,13}$ and Portugal14, as well as New Zealand ${ }^{15,16}$, Australia $^{17,18}$, the United States ${ }^{19,20}$, and Brazil ${ }^{21,22}$.
The studies based on the socio-critical perspective of PE span a vast epistemological and methodological field, bringing together theories and fundamentals of Marxism, Neo-Marxism, post-structuralism and post-colonialism ${ }^{6,23}$. Many of these studies also establish mutual relations with epistemological fundamentals of these interpretive perspectives in $P E$, epistemologically rooted in phenomenology, existentialism and postmodernism, the latter emphasising symbolic interactionism and social constructionism $^{24,25}$.

The debates regarding the goals and purposes of PE teaching have been occurring based on this theoretical construct diversity. For example, in Australian, New Zealand and North American literature one encounters the concept of physical literacy ${ }^{26,27}$, the teaching perspective known as situated learning $28,29,30,31$, as well as the movement culture concept formulated by $\mathrm{Crum}^{32}$.

The physical literacy concept has emphasised human body awareness as central to the perception process of the world as it is lived. Based on the idea of the "body" from the existentialist and phenomenological school, notably Jean-Paul Sartre and Maurice Merleau Ponty, physical literacy would be a skill - the ability to move, to develop and interact with oneself and with the world around - to be developed by school education promoting "motivation, confidence, physical competence, knowledge and understanding in order to value and take responsibility for involvement in physical activities for life"27 (p. 18).

The PE teaching perspective known as situated learning emerges from the concern with understanding what and how students learn in PE lessons. With roots in John Dewey's active learning methods and Jean Piaget's psychogenetic conception, as well as influences from the ecological psychology of James Gibson and Nikolai Bernstein, learning is characterized as a complex and dynamic interaction between the individual, the 
environment, and the task, so that the student's action in class is held as producing its own meanings and purposes, which must then be individually reflected and conceived as a process of self-construction of knowledge. Language as a mediating communicational competency is held as an important tool for reflection of and about action ${ }^{30,31}$. Some teaching methods have been systematised in the light of this perspective, such as Sport education and Sport for peace and Teaching Games for Understanding (TGfU ) $)^{28,33,34,35}$.

With respect to the movement culture ${ }^{32}$, that concept expresses the understanding that situations of teaching and learning in PE lessons possess a dimension much larger than the physical aspect of the action, relating to the development of technomotor and sociomotor skills, practical know-how and reflexive skill. Such skills would be the basis for the formation of a motor culture capable of creating conditions in for the lasting and satisfactory participation of individuals in motor and sports activities.

In Brazil, what was called the "renewal movement of Brazilian PE" emerged in the 1980s, following the process of national redemocratisation and the broadening and deepening of the ideas and practices involved in the Brazilian educational system, which in dictatorial times was marked by technicist pedagogy and its analytical idea of being human.

From this broad movement, new ideas stand out which have sought - some without much success - to overcome the ideas which have been predominant in Brazilian PE since the beginning of the $20^{\text {th }}$ century, with influences from medical, military and sports institutions.

Some of these new propositions continue to be supported by the epistemological and pedagogical base of the progressive education movement, a corollary of the modern humanist conception of education, with strong influences from the pedagogical theory formulated by John Dewey and the psychogenetic theory developed by Jean Piaget. In this context we can cite the developmental approach ${ }^{36}$ and the constructivistinteractionist approach to $\mathrm{PE}^{37}$.

Other ideas have sought their development and systematisation on new epistemological foundations, especially drawing upon theories which have made it possible to sustain new PE educational purposes stemming from different ideas of society, the human being and education underpinned by the humanities and social sciences that at the time of the country's civil-military dictatorship had no place in the Brazilian university.

In this context, we highlight the critical-emancipatory idea of $\mathrm{PE}$ conceived by Elenor Kunz ${ }^{38,21}$, based on the phenomenological and existentialist perspective of human movement as a dialogue of the subject with the existential world synthesised in the concept of "moving oneself in the world", in addition to presenting elements of Jürgen Habermas' theory of communicative action and Paulo Freire's pedagogy of liberation.

Some other, the approach known as the critical-overcoming approach of Brazilian $P E^{39,22}$ also gained recognition, conceiving the activity of teaching PE stemming from the theoreticalmethodological foundations of historical-dialectical materialism, the historical-cultural psychology of Lev Vigostki, Alexei Leontiev and Alexander Luria, as well as the pedagogical theory developed by the Brazilian educator Dermeval Saviani, known as historical-critical pedagogy $\mathrm{y}^{40,41}$.

It is through this debate that this paper has as its goal the analysis of PE's educational purposes specified in the national documents and programmes developed in Brazil and Portugal oriented towards PE education in elementary schools, at the same time seeking to observe proximities and estrangements alongside the set of theoretical-methodological formulations produced in the area's academic-professional field.

\section{Methods}

The nature of this study is of a qualitative theoreticalconceptual, documentary type ${ }^{42}$, with sources being the official documents in force at the national level in Portugal and Brazil.

The data sources were embodied in the following documents: in Portugal the National Physical Education Programmes (PNEF) - 1st, 2nd and 3rd cycles ${ }^{43,44,45,46}$, and those composing the National Basic Schooling Curriculum (CNEB) - Essential Skills ${ }^{47}$ and, in Brazil, the document National Common Curricular Base $(B N C C)^{48}$.

The criteria for source selection were: $i$ - the representativeness of the chosen documents, considering the validity, up-todateness and duration of these sources; $i i$ - the homogeneity of the documents, with a view to levelling education between the countries and; finally, iii - the adequacy of the sources to the study's goals and purposes ${ }^{49}$.

We relied on qualitative content analysis ${ }^{50,51}$, using the following analytical procedures, as befitting scientific research of a theoretical-conceptual character ${ }^{42}: i$ - pre-analysis, $i i$ - analytical description, $i i i$ - categorisation and $i v$-inferential synthesis.

The pre-analysis phase $(i-)$ consisted of understanding the meanings of the concepts presented, having in view the formulation of a primary synthesis in relation to the material in question. This phase made it possible to organise the analysed data content, determining the context unit of the analysis (data extension) and the respective registration units ${ }^{50,51}$.

The period of analytical description (ii-), made it possible to identify the explanatory guidelines (reasons) present. Here it was possible to operate analytically, by means of classification, comparison and differentiation, cropping and regrouping of data, its indicators and registration units.

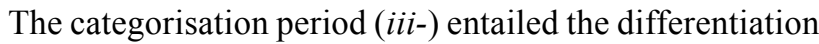
and comparative analysis of the guidelines themselves in order to determine the relative importance of each one, enabling the design of the matrix or category system of data, expression of the essential features of the documents, a general overview and summary of the essential characteristics of the documentary body.

Finally, in the process referred to as inferential synthesis (iv-) the synthesis operation was conducted, that is, performing rational integration of the data (the matrix and/or its category system) discovered regarding the research topic in question through reflexive analysis and explanatory theorisation of the issue of the educational purposes of $\mathrm{PE}$ and its correlation with the area's academic-scientific production. 
With respect to the Portuguese documents, it is important to emphasise that basic schooling (students aged between 6 and 15) in Portugal is established according to that which the Bases of the Educational System Law (Law No. 46 of October 14, 1986) referred to as the $1^{\text {st }}, 2^{\text {nd }}$ and $3^{\text {rd }}$ Cycles. The $1^{\text {st }}$ Cycle encompasses the $1^{\text {st }}$ grade to the $4^{\text {th }}$ grade; the $2^{\text {nd }}$ Cycle encompasses the $5^{\text {th }}$ and $6^{\text {th }}$ grades; and the $3^{\text {rd }}$ cycle encompasses the $7^{\text {th }}, 8^{\text {th }}$ and $9^{\text {th }}$ grades. Secondary education (the level of education of which does not form part of the research subject of this study) corresponds to the $1^{\text {st }}, 2^{\text {nd }}$ and $3^{\text {rd }}$ grades of high school in Brazil.

PE was established as a compulsory curricular subject for all Portuguese basic schooling (and also secondary schooling) by Decree-Law No. 95 of February 26, 1991. Since then, the subject has been present in the State-designed curricular plans, and its current status and validity have as reference the official constitutional documents of the National Physical Education Programmes (PNEF) - $1^{\text {st }}, 2^{\text {nd }}$ and $3^{\text {rd }}$ cycles $^{43,44,45,46}$, which form part of the general document entitled National Basic Schooling Curriculum (CNEB) - Essential Skills ${ }^{47}$.

However, the Brazilian document entitled National Common Curricular Base $(B N C C)^{48}$ has been a requirement of the Brazilian educational system since the Federal Constitution of 1988 , which established the need to define a common curricular basis for school content and learning goals in Brazilian Elementary Education (Elementary School 1 encompasses the $1^{\text {st }}$ to $5^{\text {th }}$ grades and de Elementary School 2 encompasses de $6^{\text {th }}$ to $9^{\text {th }}$ grades, overall students aged between 6 and 15).

The creation of the BNCC was begun in 2015 by the Dilma Rousseff government, with the formation of a committee of advisors and specialists made up of university professors, Elementary Education teachers, researchers and educational leaders, whose task was to design a preliminary version of the BNCC which was made available for public consultation on the Ministry of Education's website between September 2015 and March 2016.

This process was interrupted by the impeachment and permanent removal of Dilma Rousseff from the presidency, a serious rupture of the country's democratic legality. And, amongst the set of unpopular measures and setbacks stemming from this moment as implemented by the current government, the final version of the BNCC became public in April 2017 through the conclusion of work done by a steering committee established by Ministerial Decree, with a clearly prescriptive and uncompromising attitude, in addition to disregarding the set of questions and critical propositions submitted by various entities in the educational field. It is important to say that, with one voice, many entities criticise the withdrawal of democratic rights by ignoring the scholarly debate on gender, race and diversity, as well as the restriction of key subject matter by subjecting the development of new generations to the logic of the private and market interests of the country's corporate education groups.

\section{Results and Discussion}

The Brazilian and Portuguese documents conceive PE as a curricular subject responsible for developing specific and personal skills. It is evident that in both countries the development and implementation of programs and curricular guidelines follow the dominant trend of the curricular reforms that occurred in different countries (as for instance Australia, New Zealand, Czech Republic, Bulgaria, Macedonia, France, United Kingdom, Finland, Sweden, Denmark, Poland, United States of America, Chile, Peru, Portugal and Brazil, among others) in the last decades of the $20^{\text {th }}$ and early $21^{\text {st }}$ centuries, from the standpoint of developing skills-focused learning processes.

Skills based education has been adopted in the international assessments of the Organisation for Economic Co-operation and Development (OECD), whose main evaluation program is the Programme for International Student Assessment (PISA), and the United Nations Educational, Scientific and Cultural Organisation (UNESCO), the latter with significant influence on the policies of Latin American countries, especially following the establishment of the Latin American Laboratory for Assessment of the Quality of Education for Latin America (LLECE).

In the Portuguese document, a PE education programme is focused on the educational value of the physical activity oriented towards the harmonious and multilateral development of the student, education that arises from knowledge resulting from experimentation in practical activities that develop skills in the psychomotor, cognitive and socio-emotional domain ${ }^{46}$.

In the Brazilian case, experience of the practice of bodily activities and human movement is the way to generate a set of qualified skills deemed irreplaceable, enabling an increase in awareness of movements and resources for the care of self and others and to develop autonomy for appropriation and use of bodily movement culture for diverse human purposes ${ }^{48}$.

$\mathrm{PE}$ is presented in both official documents as a favourable curricular subject for skills development, since, as evidenced in the academic production of the main authors of pedagogical theories focused on the skills perspective $e^{52,53,54,55,56}$, who have a direct relationship with the studies on tacit knowledge and the epistemology of reflexive practice ${ }^{57,58,59,60,61,62,63}$. Skill is conceived as a direct synonym of satisfactory performance of practical actions in situations of real experience.

In this sense, by emphasising appreciation of the experimental and experiential dimension of behaviour, giving prominence to what is called transference and mobilisation of resources to act with pertinence and effectiveness in complex situations $^{55,56}$, PE, with its nature of practical activity, would be a favourable subject for the didactic organisation of complex and challenging tasks which incite meaningful learning through problem-solving, decision-making and active methods. It is explicit in the theoretical production of the authors that fall within the scope of the pedagogical ideology of teaching for skills development is the relation of continuity between the active pedagogies, constructivism and skills pedagogy, which emphasizes the inspirational Deweyan maxim of "learning by doing " $53,54,55,56,59,60,61,64$. As the authors themselves contend, the primary sources and origins of this growing contemporary pedagogical movement go back to John Dewey, Montessori, Tolstoy, Froebel, Pestalozzi, and even Rosseau's Emile.

Proceeding to content analysis of the selected sources, it was possible to design the following matrixes, a general overview 
and summarized expression of the analytical category system contained in each of the representative official documents of each country:

\begin{tabular}{|l|}
\hline CATEGORIES SUBCATEGORIES \\
\hline
\end{tabular}

OPERATIONAL SKILLS Physical and motor skills

\begin{tabular}{ll}
\hline CONCEPTUAL SKILLS & Knowledge about doing \\
\hline ATTITUDINAL SKILLS & Learning values and standards \\
\hline
\end{tabular}

Figure 1: Category matrix of the Portuguese document.

\begin{tabular}{|ll}
\hline CATEGORIES & SUBCATEGORIES \\
\multirow{2}{*}{ OPERATIONAL SKILLS } & Experimentation and enjoyment \\
\cline { 2 - 2 } & Use and appropriation \\
\hline \multirow{2}{*}{ CONCEPTUAL SKILLS } & Analysion in action and for action \\
\cline { 2 - 2 } ATTITUDINAL SKILLS & Comprehension \\
\cline { 2 - 2 } & Community leadership \\
\hline
\end{tabular}

Figure 2: Category matrix of the Brazilian document.

The inferential synthesis allowed the grouping and categorisation of data into three central categories in both of the documents analysed, although they were apprehended by means of different subcategories and indicators: the operational skills category, the conceptual skills category and the attitudinal skills category.

In the case of Portuguese document, the operational skills category is a direct expression of the physical and motor skills subcategory, which has as its core indicator the idea that part of the educational purposes of PE should be oriented towards the promotion of skills that lead to the development of basic functional abilities in terms of motor action and use of bodily movement in different practices and sports, dance, gymnastics, skating and sparring activities, among others.

Throughout the entire set of Portuguese documents related to the teaching of PE in the 3 cycles of basic schooling (students aged between 6 and 15), this operational skills category emerges with a quantitative percentage of $59.2 \%$ incidence in registration units (Figure 3), constituting the most prevalent category in the data analysed.

The conceptual skills category emerges in the Portuguese document supported by the knowledge about doing subcategory, which is constituted by the indicator whose central idea is to ensure a set of skills for the understanding of and reflection on practical activities carried out within the framework of PE and the conditions in which these occurred.

Such a purpose is directed to the process of knowledge and conceptual understanding of factors intrinsic to practice, as well as identification and interpretation of theoretical-practical phenomena. The percentage of incidence of this category is $16.7 \%$ of occurrence in its registration units (Fig. 3).
On the other hand, the attitudinal skills category has the learning values and standards subcategory, which has as indicator the educational purpose of development of skills and significant learning oriented towards the development of values and respect for established social standards, promotion of habits and attitudes considered healthy and stimulation of personal and group participation and success. This category appears with a percentage of incidence related to the occurrence of registration units of $24.1 \%$ (Figure 3 ).

With respect to the Brazilian document, the operational skills category appears with an expression broader than 3 subcategories. The first subcategory is that of the expression and enjoyment of the different practical activities of PE, which has as its essential indicator the development of physical-motor skills and abilities, constituting the educational purpose of developing skills for experiencing and enjoying the different types of sports, games, dances, sparring matches and gymnastics, among others.

The second subcategory of the general category of operational skills is the use and appropriation of motor culture elements in $\mathrm{PE}$, whose common indicator is to allow experiencing activities in an autonomous and creative way, constituting a skill directed towards the know-how, development, creation and recreation of individual and collective practices with purposes aimed at the procedural mastery of the same.

Finally, the third subcategory is that of reflection in action and for action, whose central indicator expresses the purpose of skills development for decision-making and practical experimental action, constituting an intentional act oriented towards the planning and employment of strategies for solving problems and challenges, as well as discussion and reflection for using of new learning in practical situations and execution of group tasks.

In its totality, the operational skills category exhibits an incidence of $54.4 \%$ in the number of occurrences in the Brazilian document (Fig. 3).

The conceptual skills category appears in the Brazilian document with a number of occurrences established at $29.1 \%$ (Fig. 3), and as constituting two other subcategories: analysis and comprehension. The first subcategory is composed of the common indicator of skills development whose purpose is focused on the conceptual knowledge necessary to understand and comprehend the constitutive elements of bodily practices, such as analysis, identification, differentiation, comparison and classification of components, instruments, games systems, rules and standards.

The second subcategory has as general indicator the development of skills that enable students to know and explain the different relationships between bodily practices and the social, historical and cultural context, contemporary problems and transversal themes, such as origin and transformations of practices, gender questions, health, environment, prejudice and social rights.

Finally, the attitudinal skills category is supported by two of the subcategories encountered: community leadership and values development. The first subcategory entails purposes that have the common indicator of developing attitudes and actions of practical intervention alongside local communities and the school surroundings, in order to build skills for the production, 
collaboration and promotion of collaborative practices and actions in the communal and regional context.

The essential core of the second subcategory is the indicator that the development of skills and learning of social and democratic values, citizenship and respect for standards is necessary. In total, the attitudinal skills category attains a $16.5 \%$ percentage of occurrences in the Brazilian example (Figure 3).

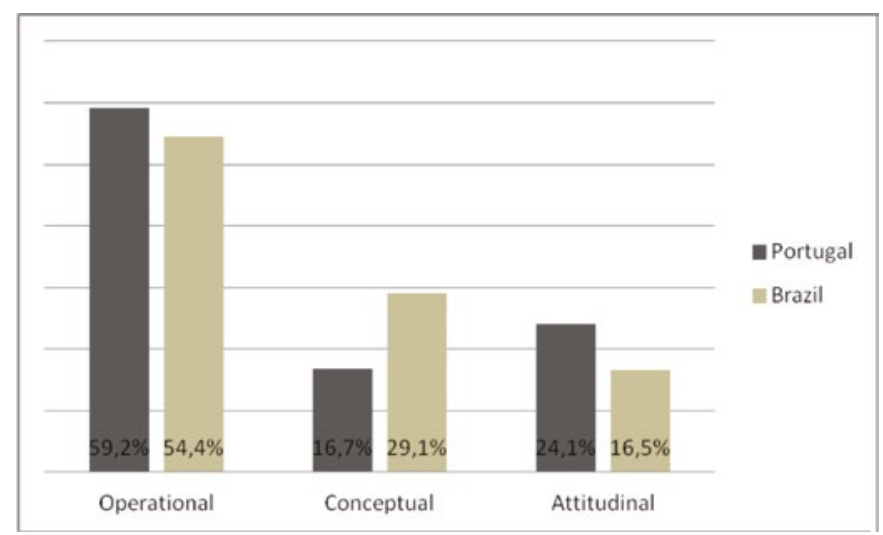

Figure 3: Distribution of category dimensions - Portugal / Brazil.

When seeking to analyse how distributions of the percentage values of each of the analytical categories occur in the official documents at each of the levels of education considered in each country, it may be observed that, in the Portuguese example, for the operational skills category there is a incidence of $28.1 \%$ in the $1^{\text {st }}$ cycle, $40.7 \%$ in the $2^{\text {nd }}$ cycle and $31.2 \%$ in the $3^{\text {rd }}$ cycle. For the conceptual skills category, there appears to be no incidence in the $1^{\text {st }}$ cycle $(0 \%), 55.6 \%$ incidence in the $2^{\text {nd }}$ cycle and $44.4 \%$ incidence in the $3^{\text {rd }}$ cycle. Finally, the attitudinal skills category appears with an incidence of $15.4 \%$ in the $1^{\text {st }}$ cycle $46.1 \%$ in the $2^{\text {nd }}$ cycle and $38.5 \%$ in the $3^{\text {rd }}$ cycle (Figure 4 ).

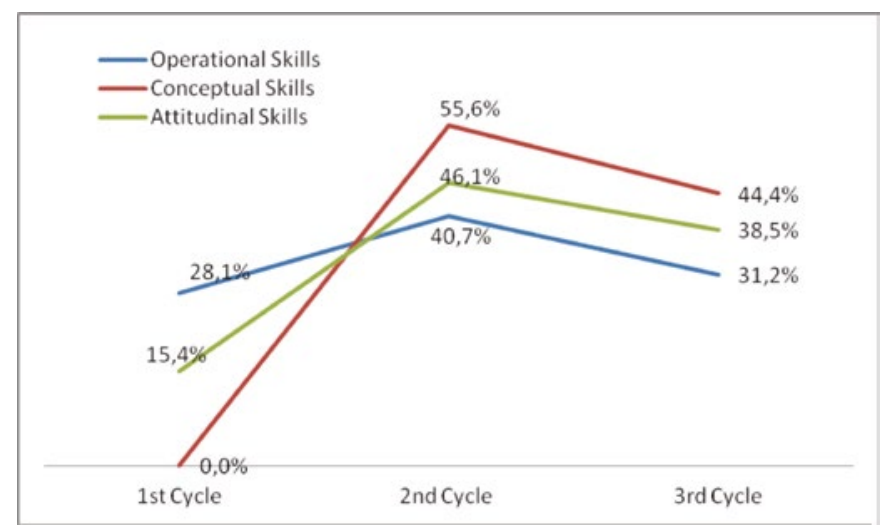

Figure 4: Skills by the level of education - Portugal.

Performing the same comparative analysis of distributions of percentage values of each of the analytical categories in each of the levels of education in the Brazilian document, it may be observed that for the operational skills category there is an incidence of $44.2 \%$ in Elementary Education $1-1^{\text {st }}$ to $5^{\text {th }}$ grades and $55.8 \%$ in Elementary School $2-6^{\text {th }}$ to $9^{\text {th }}$ grades. The conceptual skills category emerges with a distribution of
$30.4 \%$ in Elementary School 1 and 69.6\% in Elementary School 2 . Finally, the attitudinal skills category shows an incidence of $30.8 \%$ in Elementary School 1 and $69.2 \%$ in Elementary School 2 (Figure 5).

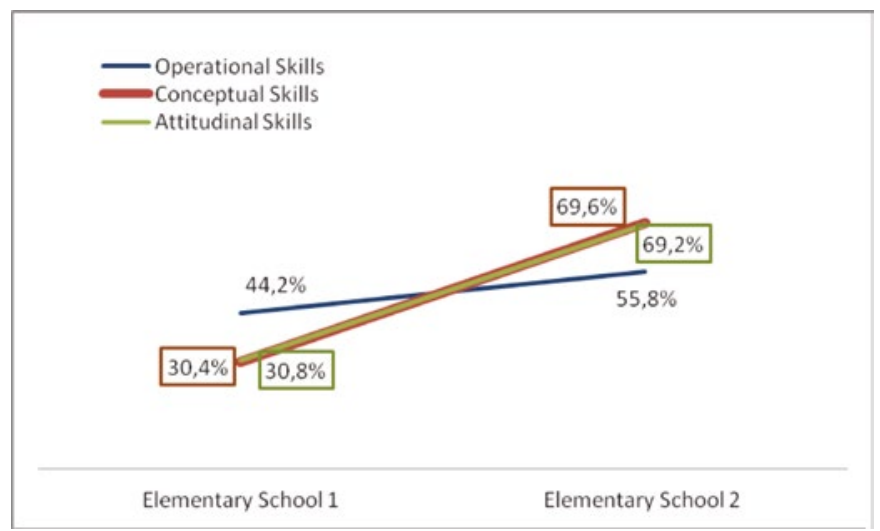

Figure 5: Skills by the level of education - Brazil.

The considerable and predominant evidence of the operational skills category in the documents of both countries (Portugal with 59.2\% incidence and Brazil with 54.4\%) is understandable and in line with the fundamentals and the inherent curricular logic of skills teaching, given that the notion that skills constitute the practical and effective action of the subjects, as stated above, is in consensus with the tradition of their development.

Meaning, the logic of skills development entails an inextricable correlation between knowledge or formative knowledge and practical-utilitarian action with a view to mobilising such knowledge in order to make decisions and solve challenges present in the daily lives of individuals.

It is commonly expressed that skills teaching is opposed to the teaching of theoretical subject knowledge which, supposedly, is said to be of no real use in the life of individuals. In this sense, skills teaching entails the corollary that skill is inseparable from the action, in teaching procedures situations that promote practical experimentation, mobilisation and transference of cognitive, perceptual, sensory and value resources with a view to acting effectively. In both documents the intrinsic and inseparable link between skill and action is explicit. The Portuguese document affirms that "The Physical Education skills are acquired through the practice of physical activity that is qualitative and quantitatively adequate to the possibilities and needs of each student" 46 (p. 220). In the Brazilian example, however, it is stated that: "[...] learning outcomes need to be expressed and presented as the possibility of using knowledge in situations that require its application in order to make pertinent decisions. This knowledge mobilised, operated and applied in situations is known as a skill"48 (p. 15).

This is the position stated by Perrenoud ${ }^{64}$ (p. 19), in saying that "[...] the students accumulate knowledge, pass the exams, but are unable to mobilise what they have learned in actual situations" and that, therefore, the development of skills teaching is an open struggle against what the author calls the temptation of the school, "[...] to teach by teaching" 
However, this is not an isolated position. Schön ${ }^{60}$, when making a distinction between school knowledge, characterised as a formal, disciplinary, categorical and negatively qualified knowledge as distant from the real daily life of the individual, and what is called tacit knowledge, a knowledge of the spontaneous type, experimental, daily, of the kind revealed by the reflexive practice in the action and for the action, alludes to the need for the school and the teachers to incorporate this second knowledge into their pedagogical practices at the expense of the first.

The assertion that theoretical and scientific knowledge devoid of its practical and everyday applicability should not permeate the development of students in school was already present in the formulations of the pragmatist philosopher John Dewey, who held, for example, that "The list of things heard or read has importance - and the bigger, the better - but only if the learner needs it and can apply it in some situation, by educating" ${ }^{65}$ ( $\mathrm{p}$. 206; original emphasis).

By means of such propositions it becomes evident why the operational skills category predominates in the curricular documents of Portugal and Brazil, both produced and guided by the formative directive of skills education, while the conceptual skills and attitudinal skills categories have less frequency values and, when apparent, show a rigid formulation oriented towards the satisfaction of development and mobilisation of their own operational skills.

In the case of the Portuguese document, it is the attitudinal skills category that appears with the highest frequency value (24.1\%) just behind the operational skills category. Apart from the intentionality of developing skills related to the formation of values of respectable and democratic coexistence, what is assumed is the purpose of developing attitudes directed towards the promotion of habits and behaviours related to participation and involvement in exercises and physical activities in such a way that their regularity becomes a proactive, healthy and harmonious lifestyle.

In this manner the intent is "To promote a taste for the regular practice of physical activities and ensure the understanding of their importance as a health factor and component of culture as relates to both the individual and social interaction" ${ }^{\prime 46}$ (p. 219), as well as "To promote the development of habits, attitudes and knowledge related [...] to physical activities" ${ }^{\prime 46}$ (p. 219).

This seems to be an element of skills development that stands out in Portugal in comparison to Brazil, given the alarming real statistics of cardiovascular and respiratory diseases, diabetes, obesity and the sedentary lifestyle of Portugal and Europe ${ }^{1,66,67}$, which makes encouraging and recommending regular physical activity in order to acquire active and healthy lifestyles something to be highlighted more and more in the various agendas of political and academic debate.

Not that this problem is absent in the Brazilian reality. However, it is the conceptual skills category (29.1\%) that stands out with a higher percentage index, just behind the operational skills category.

The educational purposes in evidence under this analytical category are mainly focused on the development of judgments, concepts and formal knowledge which allow students to understand, comprehend, differentiate, compare and classify characteristics and elements intrinsically constitutive of various bodily practices, such as "Differentiate physical exercise from physical activity" similarities between the gymnastics of bodily awareness and physical conditioning and discuss how the practice of each [...] can contribute to the improvement of living conditions, health, well-being [... $]^{\prime 48}$ (p. 195).

Also emerging, although with less frequency, still within the scope of conceptual skills, are units of meaning related to purposes aimed at the development of judgments and concepts that allow the relation of such bodily practices to the historical, social, political and economic context of which they form part, such as "Describing [...] popular jokes and games $[\ldots]$ explaining their characteristics and the importance of this historical and cultural patrimony in the preservation of different cultures" $"$ (p. 187), or even "Analysing transformations in the organisation and practice of sports in their different manifestations (professional and communal/leisure)" ${ }^{\prime 48}$ (p. 191).

The development of conceptual skills stands out even more in the Brazilian example than in the Portuguese example when we analyse the presence of this category in the different levels of education. While its presence is evident throughout all the grades of Elementary Education in Brazil, being present, therefore, from the $1^{\text {st }}$ up to the $9^{\text {th }}$ grade $(30.4 \%$ in Elementary School $1-1^{\text {st }}$ to $5^{\text {th }}$ grades and $69.6 \%$ in Elementary School $2-6^{\text {th }}$ to $9^{\text {th }}$ grades), in Portugal it only appears in the $2^{\text {nd }}$ cycle $(55.6 \%)$, whose level of education corresponds to the $6^{\text {th }}$ and $7^{\text {th }}$ grades, and in the $3^{\text {rd }}$ cycle $(44.4 \%)$ corresponding to the $8^{\text {th }}$ and $9^{\text {th }}$ grades.

We understand that all the accumulation of theoreticalconceptual discussions regarding the different conceptions of $\mathrm{PE}$, its object of study, its educational purposes and teaching and learning methodologies, under the impulse of the already discussed Brazilian PE reform movement, was able to demarcate - in the academic field and with positive resonance in political circles - the perspective of positive knowledge about doing and practicing $P E$. This particularity makes it possible to explain the most frequent presence of this category in the Brazilian document, although subsumed under the operational skills category.

Finally, it should be emphasized that we limit ourselves here to seeking to explain why the presence of this conceptual skills category is more frequent in the official Brazilian curricular programme when compared to the Portuguese case. We did not set out to analyse and qualify the actual contents under this category which allow us to delimit what knowledge, understanding, judgments and concepts are being proposed by the BNCC for the appropriation of this knowledge about doing.

\section{Conclusion}

For purposes of conclusion, it seems pertinent for us to reflect on some of the questions considered necessary in relation to the issue of the educational purposes of PE in basic education 
schools, questions which are not intended to be exhausted by presenting immediate answers, but rather to provoke reflections whose future configuration may be that of subsequent working hypotheses.

The first question is related to an undesirable opposition between theory and practice, notably a false opposition between theoretical and practical knowledge constantly present in the theories developed regarding teaching based on the logic of skills.

Despite theory and practice being different dimensions and bearing specific elements among themselves, such dimensions are inseparable and interdependent, which means the inexistence of one without the other. This entails overcoming the formal logicism so recurrent in the field of PE for which opposite poles of the same process are mutually exclusive.

Of course, if social reality is constituted as a complex set of singular individuals that establish practical relations among themselves through their various human activities, it is necessary to consider that the theoretical activity, also being configured as one of these specifically human forms of activity, was and is developed within the same social practice.

Therefore, practical human activity differs fundamentally from the activities performed by other animal beings, circumscribed to their immediate and biologically determined needs ${ }^{68}$. The practical activity of men gains characteristics that overcome this immediacy, making it a relationship mediated by theoretical activity, constituting, therefore, a practical activity rich in mediations and numerous theoretical relations. In this manner, "examined in dialectical terms, we note that instead of mutually excluding, theory and practice are opposites that include each other, opening the way for the consideration of unity between theory and practice" 69 (p. 109).

We also understand without proof the opposition that is furnished in a certain sense within the framework of skills pedagogies and the epistemology of practice between school and everyday life. Affirmations of the kind that school should be linked to life and that a school focused on theoretical knowledge is disconnected from the real life of students arises, in our view, from an equally narrow, pragmatic and short-sighted view of the relationship between knowledge and social practice.

Finally, we consider that it is necessary to re-evaluate the way we consider the presence of PE in school education, considering the useful task of rescuing PE's relationship with the school's own educational purposes, in the sense of repositioning its presence within the school curriculum in the light of the consideration of its - PE's - true nature and formative specificity, which entails recognition of its object of study, its goals, methods and teaching procedures and forms of evaluation, delimited from a given pedagogical conception of $\mathrm{PE}$.

According to Carreiro da $\operatorname{Costa}^{70}$, it is necessary that the educational work in PE is carried out with clarity and awareness of the pedagogical conception that is being developed, due to the implications that each one of the different pedagogical conceptions entails for the school PE teaching and learning framework, directly and differently impacting the purposes of teaching programmes and curricular decisions within the scope of education.
We believe that this is a safe and necessary way, but not without traps and challenges, with a view to recognising the existence of teaching and learning processes in PE that are permeated by formative educational purposes that ensure their sustainability in the school.

\section{References}

1. European Commission. Physical Education and Sport at School in Europe. Eurydice Report. Luxembourg: EU/EACEA/Eurydice, 2013.

2. Hardman K. Physical education in schools: a global perspective. Kinesiology. 2008; 40 (1):5-28.

3. Castellani Filho L. Educação Física no Brasil: a história que não se conta. 6a ed. Campinas: Papirus, 2001.

4. Crum B J. A Crise de identidade da Educação Física: ensinar ou não ser, eis a questão. Boletim Sociedade Portuguesa de Educação Física, 1993a; (7/8): 133-148.

5. Neves R. Os professores e os programas de Educação Física: representações e atitudes. Porto. Dissertação [Mestrado em Ciências do Esporte e Educação Física] - Faculdade de Ciências do Desporto e Educação Física; 1995.

6. Devís J. Socially critical research perspectives in physical education. In: The handbook of Physical Education. London: SAGE Publications Ltd., 2006.p. 37-58.

7. Kirk D. The social construction of the body in physical education and sport. In: The sociology of sport and physical education: an introductory reader. London: Routledge Falmer, 2002. p. 79-91.

8. Kirk D. Special issue: situated learning in physical education: explorations of the sport education model. Eur Phy Educ Rev. 2003; 9(3): 219.

9. Quennerstedt M, Öhman J, Öhman M. Investigating learning in physical education. The transactional approach. Sport Educ Soc. 2011; 16(2): 159-177.

10. Amade-Escot $\mathrm{C}$. The critical didactic incidents as a qualitative method of research to analyse the content thought. J Teach Phys Educ. 2005; 24: 127-148.

11. Amade-Escot C. Student learning within the didactique tradition. In: The handbook of Physical Education. London: SAGE Publications Ltd., 2006. p. 347-366.

12. Devís J. Policy, practice, and reconversion in Spanish educational reform: teaching and teacher education in physical education. The Curriculum Journal, 1997; 8: 213-230.

13. Fernández-Balboa JM. Education, telecommunications technology, and critical pedagogy in the 21 st century. Proceedings. Third International Conference on Teacher Education. The Mofet Institute: Tel-Aviv, 2000.

14. Neves R. A construção curricular da Educação Física no $1^{\circ}$ ciclo do ensino básico - conhecimento e percepção dos professores. Aveiro. Tese [Doutorado em Educação] - Departamento de Didática e Tecnologia Educativa; 2007.

15. Bevan G, Pope CC. Retrospection and ruminations on sport and physical education. J. Phys. Ed. N.Z. 2000; 33(2): 64-74.

16. Pope CC. The jagged edge and the changing shape of health and physical education in Aotearoa New Zealand. Phys Educ Sport Pedagogy. 2014; 19(5): 500-511. 
17. Macdonald D, Kirk D, Metzler M, Nilges LM, Schempp P, Wright J. It's all very well, in theory: theoretical perspectives and their applications in contemporary pedagogical research. Quest. 2002; 54: 133-156.

18. Tinning R. Toward a "modest pedagogy": reflections on the problematics of critical pedagogy. Quest. 2002; 54: 224-240.

19. O'Sullivan M. New directions, new questions: relationships between curriculum, pedagogy, and assessment in physical education. Sport Educ Soc. 2013; 18(1): 1-5.

20. Rink JE. Investigating the assumptions of pedagogy. J Teach Phys Educ. 2001; 20: 112-128.

21. Kunz E. Transformação didático-pedagógica do esporte. Ijuí: Unijuí, 1994.

22. Soares CL, Taffarel CNZ, Varjal E, Castellani Filho L, Escobar MO, Bracht V. Metodologia do ensino de Educação Física. 2a ed. São Paulo: Cortez, 2012.

23. Larsson H, Quennerstedt M. Understanding movement: a sociocultural approach to exploring moving humans. Quest. 2012; 64(4): 283-298.

24. Pope CC. Interpretative perspectives in physical education research. In: The handbook of Physical Education. London: SAGE Publications Ltd. 2006. p. 21-36.

25. Wright J. Physical education research from postmodern, poststructural and postcolonial perspectives. In: The handbook of Physical Education. London: SAGE Publications Ltd., 2006. p. 59-75.

26. Whitehead M. The concept of physical literacy. British. J TEACH PHYS EDUC. 2001; 32(1): 127-138.

27. Whitehead M. (2007). Physical literacy: philosophical considerations in relation to developing a sense of self, universality and propositional knowledge. Sport, Ethics and Philosophy. 2007; 1 : 281-298.

28. Kirk D, Macdonald D. Situated learning in physical education. J Teach in Phys Educ. 1998; 17(3): 376-387.

29. Quennerstedt M, Annerstedt C, Barker D, Karlefors I, Larsson H, Redelius $\mathrm{K}$ et al. What did they learn in school today? A method for exploring aspects of learning in physical education. Eur Phy Educ Rev. 2014; 20(2): 282-302.

30. Rovegno I. Situated perspectives on learning. In: The handbook of Physical Education. London: SAGE Publications Ltd., 2006. p. $262-274$.

31. Rovegno I, Dolly J. Constructivist perspectives on learning. In: The handbook of Physical Education. London: SAGE Publications Ltd., 2006. p. 242-261.

32. Crum BJ. Conventional thought and practice in physical education: problems of teaching and implications for change. Quest. 1993b; 45: 339-356.

33. Kirk D, MacPhail A. Teaching games for understanding and situated learning: rethinking the Bunker-Thorpe model. J Teach Phys Educ. 2002; 21: 177-192.

34. Kirk D, Kinchin G. Situated learning as a theoretical framework for sport education. Eur Phy Educ Rev. 2003; 9: 221-235.

35. Rovegno I. The development of in-service teacher's knowledge of a constructivist approach to physical education: teaching beyond activities. Res Q Exerc Sport. 1998; 69: 147-162.

36. Tani G, Manuel EJ, Kokubun E, Proença JE. Educação Física Escolar: fundamentos de uma abordagem desenvolvimentista. São Paulo: EPU, 1988.
37. Freire JB. Educação de corpo inteiro. São Paulo: Scipione, 1989. 38. Kunz E. Educação Física: ensino e mudança. Ijuí: Unijuí, 1991. 39. Soares CL, Taffarel CNZ, Varjal E, Castellani Filho L, Escobar MO, Bracht V. Metodologia do ensino de Educação Física. São Paulo: Cortez, 1992.

40. Saviani D. Escola e democracia. 41a ed. Campinas-SP: Autores Associados, 2009.

41. Saviani D. Pedagogia histórico-crítica: primeiras aproximações. 11a ed. Campinas-SP: Autores Associados, 2013.

42. Triviños ANS. Introdução à pesquisa em ciências sociais: a pesquisa qualitativa em educação. 5a ed. São Paulo: Atlas, 2009.

43. Portugal. Departamento da Educação Básica. Organização Curricular e Programas Ensino Básico - 2o Ciclo. Volume I. Lisboa: Ministério da Educação, 2001a.

44. Portugal. Departamento da Educação Básica. Programa Educação Física - Reajustamento Ensino Básico - 3o Ciclo. Lisboa: Ministério da Educação, 2001b.

45. Portugal. Departamento da Educação Básica. Programa Educação Física - Plano de Organização do EnsinoAprendizagem Ensino Básico - 2o Ciclo. Volume II. 3a ed. Lisboa: Ministério da Educação, 2003.

46. Portugal. Departamento da Educação Básica. Organização Curricular e Programas Ensino Básico - 1o Ciclo. 6a ed. Lisboa: Ministério da Educação, 2004.

47. Portugal. Departamento da Educação Básica. Currículo Nacional do Ensino Básico - Competências Essenciais . Lisboa: Ministério da Educação, 2001c.

48. Brasil. Secretaria da Educação Básica. Base Nacional Comum Curricular - Educação é a base. Brasília: Ministério da Educação, 2017.

49. Gil AC. Métodos e técnicas da pesquisa social. 6a ed. São Paulo: Atlas, 2008.

50. Bardin L. Análise de conteúdo. 6a ed. Lisboa: Edições 70, 2013.

51. Richardson RJ. Pesquisa social: métodos e técnicas. $3 \mathrm{a}$ ed. São Paulo: Atlas, 2012.

52. Delval J. Aprender a aprender. 7a ed. Campinas: Papirus, 1998.

53. Perrenoud P. Práticas pedagógicas, profissão docente e formação: perspectivas sociológicas. 2a ed. Lisboa: Don Quixote, 1997.

54. Perrenoud P. Formar professores em contextos sociais em mudança: prática reflexiva e participação crítica. Revista Brasileira de Educação, 1999a; 12: 5-19.

55. Perrenoud P. Construir as competências desde a escola. Porto Alegre: Artmed, 1999b.

56. Perrenoud P. A prática reflexiva no ofício de professor: profissionalização e razão pedagógica. Porto Alegre: Artes Médicas, 2002.

57. Nóvoa A, editor. Os professores e a sua formação. 3a ed. Lisboa: Don Quixote, 1997.

58. Pérez-Gomez A. O pensamento prático do professor: a formação do professor como profissional reflexivo. In: Os professores e a sua formação. 3a ed. Lisboa: Don Quixote, 1997. p. 95-114.

59. Schön D. Educating the reflective practitioner. Donald Schön's presentation to the 1987 meeting of the American Educational Research Association. Washington, DC, 1987. Available from: http://educ.queensu.ca/ russellt/howteach/schon87.htm. [Access 20th November 2017]. 
60. Schön D. Formar professores como profissionais reflexivos. In: Os professores e a sua formação. 3a ed. Lisboa: Don Quixote, 1997. p. 79-91.

61. Schön D. Educando o profissional reflexivo: um novo design para o ensino e a aprendizagem. Porto Alegre: Artes Médicas, 2000.

62. Tardif M. Saberes profissionais dos professores e conhecimentos universitários: elementos para uma epistemologia da prática profissional dos professores e suas conseqüências em relação à formação para o magistério. Rev. bras. educ. med. 2000; 13:5-24.

63. Tardif M. Saberes docentes e formação profissional. 7a ed. Petrópolis: Vozes, 2002.

64. Perrenoud P. A arte de construir competências. Revista Nova Escola, 2000:19-31.

65. Dewey J. Democracia e educação. Introdução à filosofia da educação. 3a ed. São Paulo: Companhia Editora Nacional, 1959.

66. European Commission. Expert group on health-enhancing physical activity. Recommendations to encourage physical education in schools, including motor skills in early childhood, and to create valuable interactions with the sport sector, local authorities and the private sector. Luxembourg: EU Work plan for sport, 2014.

67. International Council of Sport Science and Physical Education. Narrative Review - The state of Physical Activity in Europe. Pass Project. Berlin: ICSSPE, 2016.

68. Leontiev AN. O desenvolvimento do psiquismo. 6a ed. Lisboa: Livros Horizontes, 1978.

69. Saviani D. Pedagogia: o espaço da educação na universidade. Cadernos de Pesquisa, 2007; 37(130): 99-134.
70. Carreiro da Costa F. ¿Qué es una enseñanza de calidad em Educación Física? Gymnasium, 2017; 2(2):1-12.

\section{Acknowledgments}

This work is financially supported by National Funds through FCT Fundação para a Ciência e a Tecnologia, I.P., under the project UID/ CED/00194/2013.

\section{Corresponding author}

Tiago Nicola Lavoura

Av. Nossa Senhora Aparecida, 2140, Condomínio Vivêndas do Atlântico, Casa 11, Bairro Nossa Senhora da Vitória, 45655-506, Ilhéus-Bahia-Brasil.

Email: nicolalavoura@gmail.com

Manuscript received on September 27, 2018

Manuscript accepted on January 11, 2019

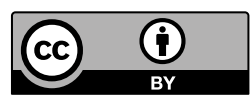

Motriz. The Journal of Physical Education. UNESP. Rio Claro, SP, Brazil - eISSN: 1980-6574 - under a license Creative Commons - Version 4.0 